\title{
AN INTERDISCIPLINARY MODEL FOR ASSESSING LEARNING
}

\author{
Robert Grover \\ Professor \\ School of Library and Information Management \\ Emporia State University \\ Emporia, Kansas 66801 USA \\ E-mail: groverro@esumail.emporia.edu \\ Jacqueline McMahon Lakin \\ Information Management Education Consultant \\ Kansas State Department of Education \\ 120 SE 10th Street \\ Topeka, Kansas 66612-1182 USA \\ E-mail: jlakin@smtpgw.ks.be.state.ks.us \\ Jane Dickerson \\ Library Media Specialist \\ Morse Elementary School \\ 15201 Monrovia \\ Overland Park, Kansas 66221-2369 USA
}

\begin{abstract}
During the 1994-95 school year the Kansas Association of School Librarians Research Committee conducted a literature review and held a two-day summer institute to develop an interdisciplinary model for assessing learning across the curriculum. Participating were teachers, administrators, library media specialists, and Kansas State Board of Education curriculum specialists. During the 1995-96 school year the committee presented the model to teachers and library media specialists at professional meetings and workshops for reactions. The model has been revised and is being tested in Kansas schools during the 1996-97 school year.

The model is based on the "Big Six" model for information problem-solving by Eisenberg and Berkowitz (1990) and is derived from an analysis of Kansas content standards for language arts, social studies, mathematics, science, reading, and library media. The model divides student assignments in these six subject areas into five parts, using terminology from the standards for each subject. Rubrics have been developed for each of the five parts of an assignment. This paper will recount development of the model, delineate elements of the model, reveal preliminary findings of the current research project which tests the model, and discuss implications for implementing the model.
\end{abstract}

\section{THE PROBLEM}

In 1991 the Kansas State Department of Education began a statewide school improvement process when it adopted the Quality Performance Accreditation system. Unlike past accreditation methods which focused on such things as the number of books in libraries or the square footage of buildings, Quality Performance Accreditation accredits schools based on student performance, i.e., a school's quality is judged by its students' academic performance and their continual academic improvement. Furthermore, the Quality Performance Accreditation system requires all educators to be collaborative in the design, implementation, and assessment of instruction. 
Since 1993 the Kansas State Department of Education, in collaboration with educators throughout the state, has developed and adopted curriculum standards in the content areas of mathematics, communication, social studies, and science. Library media specialists [teacher librarian] in Kansas have developed library media program outcomes in alignment with the U.S. government Goals 2000 program and the Kansas Quality Performance Accreditation system. These newly drafted library media program outcomes support the concept of integrated instruction as proposed in subject area curricular standards.

Parallel to the national trends for library media specialists to become engaged in the teaching of information skills integrated into subject areas at all grade levels, the Kansas Association of School Librarians (KASL) Research Committee, in collaboration with the Kansas State Department of Education, embarked on a project to develop a model for assessing learning across the curriculum.* During 1994-95 the KASL Research Committee conducted a literature review and developed a preliminary assessment model. During summer, 1995, the Committee organized a two-day summer institute to refine the model and to develop rubrics for an interdisciplinary model for assessing learning across the curriculum. Participating in development of the model were teachers, administrators, and Kansas State Department of Education curriculum specialists. In fall, 1995, the Research Committee met to review and refine the model, including the rubrics for assessment. After revising the model, the Committee members presented the model for reactions at six regional workshops sponsored by KASL. Feedback from these presentations was favorable, and suggestions were incorporated in a second revision of the model in January, 1996.

During spring, 1996, the Committee received the American Association of School Librarians/Highsmith Research Award to test the model in a sample of Kansas schools. This paper will describe the Interdisciplinary Assessment Model, preliminary results of research testing the model, and implications for implementation of the model in schools.

Development of an integrated assessment model required establishment of a common language for library media specialists to work in various curriculum areas, a comparison of current state standards for subject areas, and, finally, creation of rubrics for each stage of the assessment model. Each of these steps will be discussed in turn.

\section{IN SEARCH OF A COMMON LANGUAGE}

"Assessment of student learning, the measuring of student's progress and performance... is being given serious attention across disciplines and at all levels of education." (Kuhlthau, 1994, p. IX) The problem encountered by library media specialists is integrating assessment across disciplines and grade levels. Needed is a common language, or model, to allow grade level or curricular area experts to communicate effectively.

Library media specialists currently integrate knowledge of the learning outcomes of each discipline or level of education with outcomes for critical thinking and information problem solving skills. Integration of instruction and assessment at this level demands an understanding of the vocabulary of each discipline as well. The goal of the KASL Research Committee was to find a common language among the Kansas State Department of Education assessment guidelines for reading, mathematics, social studies, science, Six-Trait Writing, and information problem-solving.

The Eisenberg and Berkowitz (1990) Big Six model provides the common language for library media specialists teaching information problem-solving. This model presents six steps for problem solving:

1. Task Definition: define the problem and identify the information requirements of the problem.

2. Information Seeking Strategies: Determine the range of possible sources and evaluate the different possible sources to determine priorities.

3. Location and Access: Locate sources (intellectually and physically) and find information within sources.

4. Information Use: Engage (e.g., read, hear, view) the information in a source and extract information from a source.

5. Synthesis: Organize information from multiple sources and present the information. 
6. Evaluation: Judge the product (effectiveness) and judge the information problemsolving process (efficiency). (p. 24)

This Big Six model became the framework for establishing a common language across disciplines. The other common ground was the teaching process. The problem of interdisciplinary collaboration involves synthesizing complex, specific language and learning outcomes into a model that can be used effectively by teachers from all disciplines and grade levels and by library media specialists.

The common language for interdisciplinary collaboration evolved from an examination of the teaching process by Jane Dickerson, library media specialist at Morse Elementary School, Blue Valley Schools, Kansas. Ms. Dickerson perused Kansas standards for reading, mathematics, social studies, science, and Six-Trait Writing, as well as The Big Six, and created the following model which serves as the "common language" for these areas, with teaching as its focus. This teaching model identifies the following five steps, which are defined below:

1. Assignment

2. Plan of action

3. Doing the job

4. Finished product

5. Evaluation

All teacher/library media specialist collaborative teams begin with an assignment. This assignment aligns district and school curricular learning outcomes with appropriate discipline/grade level/unit outcomes. This integrated assignment and its outcomes are directly tied to the assessment that will allow the collaborative team to determine each student's current progress. The assignment requires the student to have a clear, complete understanding of the

assignment or problem. The assignment creates a focus for successful task completion and evaluation.

The plan of action occurs when the teacher(s) and the library media specialist determine which discipline-related, problem-solving, and instructional strategies the student must use to complete the assignment successfully. The plan of action requires the student to choose the most appropriate strategy(ies) and give reasons for his/her choice(s). The plan of action may entail the analysis of tools, experiences, and available resources that would facilitate meeting the requirements of the assignment.

Doing the job causes the student, teacher(s) and library media specialist to focus on the requirements needed to complete the assignment (job) with all components in evidence. To successfully do the job, the student must have a clear understanding of the assignment/problem and choose the most appropriate strategy(ies) for completing the assignment. This step of the teaching model combines steps three and four of the Big Six, i.e., Location and Access, and Information Use.

The finished product, the completed assignment, reflects quality and the student's understanding of most facets of the problem. This product may be a correct response to a question, the solution to a mathematical equation, a report, chart, cooperative learning activity, research paper, or invention, as well as other forms of authentic assessment.

Evaluation is conducted by the teacher(s) and library media specialist with the student to appraise the student's completion of the assignment. The evaluation must be aligned with the assignment, the plan of action, doing the job, and the finished product. This evaluation rates the product and problem-solving process and requires the student to give reasons for the evaluation. Such assessment may enhance opportunities for the student to transfer this knowledge to a "real life" situation. 


\begin{tabular}{|c|c|c|c|c|c|c|}
\hline $\begin{array}{c}\text { Integrated } \\
\text { Model }\end{array}$ & $\begin{array}{c}\text { Information } \\
\text { Problem } \\
\text { Solving }\end{array}$ & Reading & Math & $\begin{array}{l}\text { Social } \\
\text { Studies }\end{array}$ & Science & $\begin{array}{c}\text { Six-Trait } \\
\text { Writing }\end{array}$ \\
\hline Assignment & Define Task & $\begin{array}{l}\text { Read selection } \\
\text { Read question }\end{array}$ & $\begin{array}{l}\text { Understand the } \\
\text { problem }\end{array}$ & $\begin{array}{l}\text { Identify } \\
\text { Issue for } \\
\text { investigation }\end{array}$ & $\begin{array}{l}\text { Recognize } \\
\text { and define } \\
\text { the problem }\end{array}$ & $\begin{array}{l}\text { Develop } \\
\text { ideas \& } \\
\text { content for } \\
\text { audience }\end{array}$ \\
\hline $\begin{array}{l}\text { Plan of } \\
\text { action }\end{array}$ & $\begin{array}{l}\text { Develop } \\
\text { information } \\
\text { seeking } \\
\text { strategies }\end{array}$ & $\begin{array}{l}\text { Outline key } \\
\text { terms \& } \\
\text { concepts }\end{array}$ & $\begin{array}{l}\text { Choose problem } \\
\text { solving strategy }\end{array}$ & $\begin{array}{l}\text { Develop a } \\
\text { plan for the } \\
\text { investigation }\end{array}$ & $\begin{array}{l}\text { Design a } \\
\text { problem } \\
\text { solving } \\
\text { strategy }\end{array}$ & $\begin{array}{l}\text { Further } \\
\text { develop } \\
\text { ideas and } \\
\text { content for } \\
\text { audience }\end{array}$ \\
\hline $\begin{array}{l}\text { Doing the } \\
\text { job }\end{array}$ & $\begin{array}{l}\text { Locate, access } \\
\& \text { use } \\
\text { information }\end{array}$ & $\begin{array}{l}\text { Choose } \\
\text { appropriate } \\
\text { information } \\
\text { sources }\end{array}$ & $\begin{array}{l}\text { Implement a } \\
\text { problem solving } \\
\text { strategy }\end{array}$ & $\begin{array}{l}\text { Acquire } \\
\text { information } \\
\text { from } \\
\text { sources; } \\
\text { organize } \\
\text { information }\end{array}$ & $\begin{array}{l}\text { Implement a } \\
\text { problem } \\
\text { solving } \\
\text { strategy }\end{array}$ & $\begin{array}{l}\text { Refine the } \\
\text { voice } \\
\text { including } \\
\text { strategy } \\
\text { flow; } \\
\text { proofread }\end{array}$ \\
\hline $\begin{array}{l}\text { Finished } \\
\text { product }\end{array}$ & $\begin{array}{l}\text { Synthesize \& } \\
\text { present the } \\
\text { information }\end{array}$ & $\begin{array}{l}\text { Apply } \\
\text { appropriate } \\
\text { information } \\
\text { sources }\end{array}$ & $\begin{array}{l}\text { Find \& report } \\
\text { conclusion }\end{array}$ & $\begin{array}{l}\text { Choose \& } \\
\text { justify on } \\
\text { the issue; } \\
\text { present } \\
\text { results }\end{array}$ & $\begin{array}{l}\text { Interpret \& } \\
\text { communicate } \\
\text { findings \& } \\
\text { conclusions }\end{array}$ & $\begin{array}{l}\text { Submit to } \\
\text { editor; } \\
\text { revise }\end{array}$ \\
\hline Evaluation & $\begin{array}{l}\text { Evaluate } \\
\text { process \& } \\
\text { product }\end{array}$ & $\begin{array}{l}\text { Check } \\
\text { response for } \\
\text { understanding, } \\
\text { accuracy \& } \\
\text { completeness }\end{array}$ & $\begin{array}{l}\text { Evaluate } \\
\text { conclusion for } \\
\text { reasonableness } \\
\text { of results }\end{array}$ & $\begin{array}{l}\text { Evaluate } \\
\text { process \& } \\
\text { product of } \\
\text { the } \\
\text { investigation }\end{array}$ & $\begin{array}{l}\text { Evaluate } \\
\text { findings for } \\
\text { clarity, } \\
\text { accuracy \& } \\
\text { real life } \\
\text { applications }\end{array}$ & $\begin{array}{l}\text { Publish; } \\
\text { evaluate } \\
\text { for } \\
\text { audience } \\
\text { reception } \\
\text { \& logic }\end{array}$ \\
\hline
\end{tabular}

Table 1: Comparing Teaching Stages Across Subject Areas 
The terms in the integrated teaching model represent a common language for discussing instruction with teachers from various subject areas. Using this model and The Big Six, terms were drawn from Kansas subject area standards to prepare the following table of comparisons.

\section{DESIGNING RUBRICS FOR AN INTEGRATED ASSESSMENT MODEL}

Numerous assessment strategies were reviewed by the Research Committee, resulting in the selection of rubrics for application in the integrated assessment model. Rubrics are guidelines for evaluation; they are intended to provide qualitative descriptions or measures of the student's progress towards stated outcomes. Rubrics were developed, submitted to practitioners for reaction, and revised. Based on these reactions and preliminary application in classrooms, a generic rubric was created. The KASL Research Committee designed a rubric with four levels plus a state of nonachievement. Following are these levels, with level \#4 the highest level of achievement:

NA Not applicable or no evidence is available

1 Awareness

$2 \quad$ Understanding

3 Demonstration

4 Application

A rating of NA indicates that the student has produced no evidence that s/he attempted to address the assignment. There is no basis for evaluation.

A rating of 1 indicates awareness or knowledge of the process or product, as indicated by evidence the teacher and library media specialist have gathered. For example, in stage 1, the integrated assignment, the student in some way demonstrates awareness of the assignment or problem, e.g., verbally, nonverbally, or through a product.

"Understanding," a rating of $\mathbf{2}$, indicates that the student has a basic comprehension of the problem or process, often expressed verbally.

"Demonstration," a rating of $\mathbf{3}$, results from evidence provided by behavior and/or example.

Rating 4, "application," suggests that the student has integrated the knowledge and is able to apply it in a real-life situation.

For each stage of the model, i.e., "Integrated Assignment," "Integrated Plan of Action," etc., the rubric described above is applied. For example, the "Integrated Assignment" provides the following rubrics:

$4 \quad$ Articulates a clear, complete understanding of assignment/problem.

3 Demonstrates understanding of most of assignment/problem.

2 Shows vague, unfocused understanding of assignment/problem.

1 Is aware of assignment/problem.

NA Not applicable/nothing available

The rubrics for each stage of the model are presented in Table 2. These rubrics, combined with the integrated teaching model, provide library media specialists and teachers with a tool for planning, implementing, and assessing the integrated teaching of information skills. The complete model is found in the appendix. The section which follows describes the research which is testing the assessment model. 


\begin{tabular}{|c|c|c|c|c|}
\hline $\begin{array}{l}\text { Integrated } \\
\text { Assignment }\end{array}$ & $\begin{array}{c}\text { Integrated } \\
\text { Plan of Action }\end{array}$ & $\begin{array}{l}\text { Integrated } \\
\text { Doing the J ob }\end{array}$ & $\begin{array}{l}\text { Integrated } \\
\text { Finished } \\
\text { Product }\end{array}$ & $\begin{array}{l}\text { Integrated } \\
\text { Evaluation }\end{array}$ \\
\hline $\begin{array}{l}\text { 4-Articulates a clear, } \\
\text { complete } \\
\text { understanding of } \\
\text { assignment/ problem. }\end{array}$ & $\begin{array}{l}\text { 4-Chooses the } \\
\text { most appropriate } \\
\text { strategy(ies) and } \\
\text { gives reasons for } \\
\text { choice. }\end{array}$ & $\begin{array}{l}\text { 4-Completes the } \\
\text { assignment (job) } \\
\text { with all } \\
\text { components in } \\
\text { evidence. }\end{array}$ & $\begin{array}{l}\text { 4-The quality of } \\
\text { the product } \\
\text { reflects an } \\
\text { understanding of } \\
\text { most facets of the } \\
\text { problem. }\end{array}$ & $\begin{array}{l}\text { 4-Evaluates the } \\
\text { product and } \\
\text { problem-solving } \\
\text { process and gives } \\
\text { reasons without } \\
\text { assistance. }\end{array}$ \\
\hline $\begin{array}{l}\text { 3-Demonstrates } \\
\text { understanding of most } \\
\text { of assignment } \\
\text { / problem. }\end{array}$ & $\begin{array}{l}\text { 3-Chooses a } \\
\text { strategy after } \\
\text { comparing } \\
\text { possibilities }\end{array}$ & $\begin{array}{l}\text { 3-Submits the } \\
\text { assignment (job) } \\
\text { with few } \\
\text { components } \\
\text { missing. }\end{array}$ & $\begin{array}{l}\text { 3-The quality of } \\
\text { the product } \\
\text { reflects an } \\
\text { understanding of } \\
\text { many facets of } \\
\text { the problem. }\end{array}$ & $\begin{array}{l}3 \text {-Evaluates the } \\
\text { product and } \\
\text { problem-solving } \\
\text { process and gives } \\
\text { reasons with } \\
\text { assistance. }\end{array}$ \\
\hline $\begin{array}{l}\text { 2-Shows vague, } \\
\text { unfocused } \\
\text { understanding of } \\
\text { assignment/ problem. }\end{array}$ & $\begin{array}{l}\text { 2-Chooses a } \\
\text { strategy without } \\
\text { comparison to } \\
\text { other } \\
\text { possibilities. }\end{array}$ & $\begin{array}{l}\text { 2-Submits } \\
\text { assignment (job) } \\
\text { with many } \\
\text { components } \\
\text { missing. }\end{array}$ & $\begin{array}{l}\text { 2-The quality of } \\
\text { the product } \\
\text { reflects } \\
\text { understanding of } \\
\text { some facets of } \\
\text { the problem. }\end{array}$ & $\begin{array}{l}\text { 2-Understands } \\
\text { the evaluation } \\
\text { process but gives } \\
\text { few reasons, } \\
\text { even with } \\
\text { assistance. }\end{array}$ \\
\hline $\begin{array}{l}1 \text {-Is aware of } \\
\text { assignment/ problem. }\end{array}$ & $\begin{array}{l}1 \text {-Is aware of } \\
\text { different } \\
\text { strategies. }\end{array}$ & $\begin{array}{l}\text { 1-Is aware of } \\
\text { assignment (J ob) } \\
\text { but has difficulty } \\
\text { proceeding. }\end{array}$ & $\begin{array}{l}\text { 1-The quality of } \\
\text { the product } \\
\text { reflects } \\
\text { understanding of } \\
\text { few facets of the } \\
\text { problem. }\end{array}$ & $\begin{array}{l}\text { 1-Completes the } \\
\text { assignment but } \\
\text { cannot give } \\
\text { reasons for the } \\
\text { errors in the } \\
\text { product and } \\
\text { problem-solving } \\
\text { process. }\end{array}$ \\
\hline $\begin{array}{l}\text { NA-Not } \\
\text { applicable/ nothing } \\
\text { available. }\end{array}$ & $\begin{array}{l}\text { NA-Not } \\
\text { applicable/ nothing } \\
\text { available. }\end{array}$ & $\begin{array}{l}\text { NA-Not } \\
\text { applicable/ nothing } \\
\text { available }\end{array}$ & $\begin{array}{l}\text { NA-Not } \\
\text { applicable/ nothing } \\
\text { available }\end{array}$ & $\begin{array}{l}\text { NA-Not } \\
\text { applicable/ nothing } \\
\text { available }\end{array}$ \\
\hline
\end{tabular}

Table 2: Rubrics for the Integrated Assessment Model 


\section{OVERVIEW OF THE STUDY}

The KASL Research Committee identified Research Advisory Committee members who typified staff from the Kansas State Department of Education, school library media specialists at various levels, subject area teachers, and school administrators. The Research Advisory Committee met twice in August, 1996, to recommend research strategies and possible schools to participate in the study. The Advisory Committee monitor the project through reports sent by the project chair to members.

To assist in the planning and implementation of the project, the Research Committee identified an independent research consultant, Delia Neuman, Associate Professor, College of Library and Information Services, University of Maryland. Dr. Neuman participated in the design of the study, selection of research methods, and selection of schools by participating in meetings of the Research Advisory Committee. She also has participated by telephone in meetings of the researchers to address researchers' questions regarding data collection techniques and analysis of results.

Following are the research questions adopted for the project:

1. How does the model's usage facilitate student learning in selected grade levels and subject areas?

2. How does use of the model influence collaborative planning and integrated instruction?

\section{Selecting Schools}

Schools were selected to assure diversity on each of the following criteria: (1) level, i.e., elementary, middle school, high school; (2) size of school, (3) whether rural, suburban, or urban; (4) school climate, i.e., amount of integration of the teaching of information skills; and (5) library media specialist knowledge of the assessment model (all had attended workshops at which the model was described and used).

Due to time constraints (the researchers are employed in professional positions which limit their availability for travel and data collection), two categories of participating schools were established-case study schools and self-reporting schools. In consultation with the project consultant, the researchers agreed to concentrate efforts on three sites, representing elementary, middle, and high schools. These were designated "case study schools." One researcher was assigned to work with each case study school on a regular basis to visit, conduct interviews, and observe use of the model. The researchers observed lesson presentations and interviewed participating teachers and library media specialists. The researchers also regularly contacted the library media specialists by telephone.

A second type of school was designated "self-reporting." Library media specialists at selfreporting schools completed a "School Information Form," and their "research partner," a member of the Research Committee, contacted the library media specialist approximately every two weeks, using an interview guide. No school visits were made, but continuous monitoring of the model's use was accomplished through telephone contact.

\section{RESEARCH METHODS}

Research methods were recommended during the meetings of the Research Advisory Committee and during subsequent phone consultations with the research consultant. Phone conferences with the research consultant were augmented with faxed copies of instruments developed by the researchers and electronic mail communication. Instruments were created to gather data collected through interviews, classroom observations, and school walkarounds.

Precise data-gathering instruments were required to ensure standardization of data collection by the team of researchers, who included one half-time elementary school library media specialist, two full-time elementary school library media specialists, two high school library media specialists, one graduate student, one state department consultant, and one library and information science school faculty member. One researcher was assigned to each of the ten participating schools. Researchers working with case study schools had that school as their only assignment, while researchers working with self-reporting schools had one or two schools assigned. The graduate student and faculty member, who had more flexibility in their daily schedules, were assigned to 
gather data in any of the schools should an assigned researcher be unable to gather data at a critical time.

During the planning process, the researchers decided to make every effort to gather data during the planning, implementation, and summative evaluation stages of units.

Preliminary Results

By December, 1996, the three case study schools had each completed at least one unit of study using the integrated assessment model. The seven self-reporting schools had completed a total of four units, with one unit incomplete. The researchers met to review preliminary results, based on ten weeks of observations and interviews. During this meeting researchers met in two groups, those working with self-reporting schools and those working with case studies, to synthesize their findings to date. The researchers then shared their preliminary findings with each other and with the research consultant (via telephone conference). The two groups of researchers found that their results were compatible.

Additional data were collected during the conduct of a series of two workshops given in a school district during the first two months of 1997. These workshops were funded by a grant to improve assessment and integration of science teaching. Attending were 42 teachers representing all curricular areas in all grade levels. During the first workshop teachers were instructed on use of the model and asked to use the model to develop a unit of instruction during the intervening weeks between the workshops. During the second workshop session teachers assessed their experiences, and comments made during the ensuring discussion were noted. These reactions have been incorporated with data gathered at the other participating schools.

\section{Research Question \#1: How does the model's usage facilitate student learning in selected grade levels and subject areas?}

According to preliminary results, teachers and library media specialists said that the model facilitated student learning in all grade levels studied and for units of any length. Furthermore, they reported that the "integrated assignment" stage of the model was a key to enhancing student learning. Following is a summary of interview results:

1. Students knew what they were doing and were on task.

2. Students had a sense of participating in the learning process.

3. Students demonstrated pride in the finished product.

4. Student learning is higher quality learning, i.e., teachers and Library media specialists said that students were employing higher level thinking skills after using the model.

5. Students were responsible for their learning, enhancing critical thinking.

6. Students learned that research can be a relatively simple process, like gathering data about book characters.

7. Students asked good questions.

8. The model makes students aware of what's expected of them.

9. The model is an advanced organizer which frees students to pursue the content.

\section{Research Question \#2: How does use of the model influence collaborative planning and integrated instruction?}

While the integrated model is an assessment of student performance, preliminary results suggest that the model is a useful teaching tool. The model gives teachers and library media specialists a "handle" on information use and how it can be taught as a learning process. The library media specialists reported that the integrated assessment model is an effective and efficient planning tool which:

1. Enables the teacher to check the student's pre-knowledge;

2. Moves learning outcomes to the beginning of the project;

3. Makes it easier for a school to tie everyday instruction and assessment to the school improvement plan;

4. Encourages teacher/library media specialist collaboration, enhancing teacher satisfaction by working with other staff members; 
5. Apparently works with short (TWO day) as well as longer (several week) units; and

6. Improves teaching by keeping the teacher focused on outcomes and assessments. In short, this model appears to be a tool which benefits teachers at least as much as students.

\section{IMPLEMENTATION ISSUES}

After attempting to implement the model, teachers, library media specialists, and researchers reported that the model is complex and that successful implementation requires adequate instruction. Introducing the model without follow-up does not ensure successful implementation. Following are implementation issues which have emerged:

1. Although the description of the model indicates that the integrated assignment and its outcomes are directly tied to assessment, the impact of this connection is sometimes underestimated by teachers and library media specialists. Some of the teachers were comfortable giving the assignment but did not know how to assess learning. Other teachers did not assess at all the students' understanding of the assignment. Those who did assess the assignment found that students were more likely to complete the assignment accurately, i.e., meeting the assignment's objectives. Our preliminary results indicate that assessing students' understanding of the assignment is the single most effective way of ensuring student success.

2. While teachers may be aware that students have vastly different and unique learning styles, their teaching strategies often do not reflect these student differences. Teachers tend to revert to traditional learning activities, e.g., written reports and oral presentations, without providing students the opportunity to use such talents as Gardner's spatial, interpersonal, bodily kinesthetic, intrapersonal, and musical intelligences (Gardner, 1993).

3. The "plan of action" of a unit should provide students a variety of strategies for completing the study; however, the options may be severely limited by the resources available at a school. A wide range of materials, formats, types of materials, and reading levels should be made available to address the wide range of students' abilities.

4. "Doing the job" was effectively accomplished by library media specialists and teachers in the study. Students are accustomed to completing learning tasks in the school and teachers are accustomed to supervising these activities.

5. The "finished product" assessment often confuses formative and summative evaluation. Teachers often assess the finished product but fail to work with students to assess the learning process-part of the "evaluation" step of the five-step assessment model.

6. Assessment of the "finished product" should include product-specific assessments to evaluate better the student's learning. The specificity is directly related to the requirements of the assignment. In addition, the assessments should go beyond "paper and pencil" assessments to enable students to use their unique abilities to demonstrate learning.

7. Teachers and library media specialists should be able to differentiate between a product and a process during assessment. They need to understand that both product and process play a role in student learning and are interrelated. Both have importance and both should be used in assessment activities. Typically, teachers evaluate products but do not encourage students to recognize and evaluate the process. Moreover, the product evaluations are usually teacher evaluations, neglecting to encourage student reflection and peer evaluation of products. In today's rapidly changing "information age," it is not possible to learn all of the facts or "content"; however, it is possible and desirable for schools to teach a learning process. This process should be routinely assessed.

8. Teachers must have a knowledge of the differences between criterion-referenced reporting and normative-referenced reporting of assessments. Traditionally, in norm-referenced terms, we think of comparing students to a national or state mean, for example, a standardized test like the Iowa Test of Basic Skills or the California Test of Basic Skills. Often, these comparisons do not have relevance to the classroom teacher, the school, or the student. By contrast, criterion referenced reporting compares the student's performance to a standard of excellence established by the teacher, the school, or the state. These standards are directly aligned with the school's curriculum and the classroom teacher's instruction and assessment. Also, since the standards are tied directly to classroom instruction and assessment, they have more relevance for the student learner.

9. By using the integrated assessment model, library media specialists are involved in the assessment of the finished product. Traditionally, library media specialists are involved in design of 
the assignment, the plan of action, and doing the job. However, assessment has been left almost solely to the classroom teacher. Use of the integrated assessment model encourages the library media specialist to be engaged in assessment at all five stages of the learning/teaching process.

10. There is a need for support documents for library media specialists and teachers to implement successfully the assessment model. These documents should include sample lesson plans, lesson plan formats, grade sheets based on the five steps of the model, and examples of assessments that reflect multiple intelligences, moving beyond traditional pencil and paper tests.

11. The model should be expanded to include fine arts and vocational education in order to be useful across the curriculum. The arts, especially, enable integration of cultural studies to include literature, music, art of all types, theater, and dance.

In summary, successful implementation of the five-step integrated assessment model requires library media specialists and teachers to reconsider their roles working with students. If we truly believe that all students can learn and that the role of teachers and library media specialists is to enhance learning, new ways of structuring the learning process must include systematic and frequent assessment throughout the learning process. The five-step model provides a framework for planning learning activities to accommodate frequent and systematic evaluation for the benefit of the students' success.

\section{CONCLUSION}

The need for improved assessment of learning, especially the assessment of critical thinking and problem solving, was the stimulus for creating the Interdisciplinary Assessment Model. It is the result of a review of professional literature and of the collective thinking of library media specialists, teachers, school administrators, and university faculty. Creation of the model required an examination of assessment strategies, establishment of a common language for library media specialists to work in various curriculum areas, and a comparison of current state standards for subject areas.

Implementation of the model has been the subject of research by the KASL Research Committee and Kansas State Department of Education, revealing that the integrated assessment model is effective as a planning and teaching tool for library media specialists and teachers. Research has also revealed that effective implementation requires instruction and tools which will enable teachers to change their instructional strategies to more effectively engage the student learner and to provide feedback to the learner.

Revision of the model will occur after the Research Committee analyzes the findings of research when the data-gathering is completed. At that time, the Committee will consider addition of the arts and vocational education to the integrated assessment model.

\section{NOTES}

While the persons listed were responsible for writing this paper, all Kansas Association of School Librarians Research Committee members contributed ideas to the model presented here. Those committee members are: Shelia Blume, Judy Burbach, Carol Fox, Jim Hathaway, Latane Kreiser, Betsy Losey, Roma McConkey, Mary Schumacher, and Rosemary Talab.

\section{REFERENCES}

Eisenberg, M. B., \& Berkowitz, R. E. (1990). Information problem-solving. Norwood, NJ: Ablex. Gardner, H. (1993). Multiple intelligences: The theory in practice. New York: BasicBooks.

Kuhlthau, C. C. (1994). Assessment and the school library media center. Englewood, CO: Libraries Unlimited. 